\title{
Arthur George Perkin, D.Sc., F.R.S.
}

DURING the last quarter of the nineteenth and the first quarter of the twentieth century no name has been more prominent in the literature of Organic Chemistry than that of Perkin. William Henry Perkin, sen. (later Sir), had two sons by his first marriage-William Henry, jun., and Arthur George-and one son by his second marriage-Frederick Mollwo. All three sons followed in their father's footsteps. "W. H., jun." was best known for his syntheses of not only "ring," but of "bridged ring" compounds. "A. G.", as we shall see, became an authority on "Tinctorial Chemistry"; while "F. M." interested himself speçally in electrolytic oxidation and in low temperature carbonisation.

Arthur George Perkin was born on December I3, I86I. He attended the City of London School and then the Royal College of Chemistry. At the latter institution he came under Frankland and Guthrie, and in I 880 there appeared in the Journ. Chem. Soc. his first "Contribution""The Action of Nitric Acid on Diparatolylguanidin" (vol. xxxvii, I88o, p. 696). From London he went to Glasgow, where he spent a year with Professor E. J. Mills at Anderson's College. His next move was to Yorkshire College, Leeds, where began what, after an interval of ten years, became his permanent association with the great "Dyeing School" of the College, later known as the University of Leeds. After a year with Professor J. J. Hummel, in which they investigated "Hæmatin and Brazilien" (Journ. Chem. Soc., vol. xli, 1882, p. 367), he was appointed chemist in the Alizarine Factory of Hardman and Holdens, Manchester, becoming manager in I 888. Business, however, did not offer attractions to him, and a couple of years later the Heriot-Watt College, to which "W. H., jun." had been called, gave accommodation to him and also to the youngest brother. The three Perkins, along with F. Stanley Kipping, formed a powerful team, and the Heriot-Watt College became a centre of chemical activity. The attraction of the "Dyeing School" at Leeds, however, prevailed, and from 1892 until his death on May 30 , 1937, A. G. Perkin occupied successively the positions of Lecturer, Professor of Tinctorial Chemistry (from I9I5), and, after retirement, Professor Emeritus.

In Leeds also he found his bride, Annie Florence Bedford, who survives him.

A. G. Perkin was an assiduous worker in the laboratory. The 
Journal of the Chemical Society contains nearly sixty contributions in his own name and more than seventy in conjunction with others. These contributions are all concerned directly or indirectly with colouring matters. Many investigations were carried out on Indigo; on the Yellow Colouring Principles of Tannin Matters; on Colouring Matters of Cotton Flowers; on various colouring principles such as Apiin, Chrysin, Gentisin, Hesperitin, Maclurin, Morin, Myricetin, Quercetrin, Robinin; on derivatives of Anthracene, Anthraquinone, Oxanilide.

A measure of the chemical activity of the Perkin family may be got from the Collective Index of the Chemical Society, where in the period I893-1902 three pages (double column), and in 1903-I9I2 four pages, are occupied by the family! During the Great War, "A. G." rendered important service in connection with the dye-stuff industry, and after it he continued his investigations, though not with the same energy as before, his last paper appearing in $193 \mathrm{I}$.

In conjunction with A. E. Everest, he wrote a book, Natural Organic Colouring Matters, in which much of his own work is summarised. He also contributed articles to the Encyclopadia Britannica and to Thorpe's Dictionary of Applied Chemistry.

A modest, unassuming nature endeared "A. G." to those admitted to his friendship. Both "W. H." and "A. G." had musical attainments, and the writer has pleasant recollections of the performances of "A. G." on the flute to the pianoforte accompaniment of his brother.

He was elected a Fellow of the Royal Society of Edinburgh in I893 and ten years later a Fellow of the Royal Society. The Davy Medal of the Royal Society was awarded to him in 1925 , and on his retirement from the Chair of Tinctorial Chemistry the University of Leeds conferred upon him the Honorary Degree of D.Sc.

See also Obituary Notices of Fellows of the Royal Society, vol. ii, No. 6, 1938 .

J. E. M. 